\title{
Assessing Water Quality and Its Relationship to Selected Disease Patterns in Zvishavane Town, Zimbabwe
}

\author{
${ }^{* 1}$ MULEYA, E; ${ }^{1}$ NYOMOMBE, T; ${ }^{2}$ MAPHOSA, NS; ${ }^{1}$ MATUNHU V \\ ${ }^{1}$ Department of Metallurgical and Materials Engineering, ${ }^{2}$ Department of Development Studies, Midlands State University, P.O. Box 100, \\ Zvishavane, Zimbabwe \\ ${ }^{3}$ Department of Geography and Environmental Science, University of Zimbabwe, P. O. Box MP 167. Mount Pleasant Harare. \\ ${ }^{* 1}$ Corresponding Author Email: muleyae@staff.msu.ac.zw; Cell +263778739201
}

\begin{abstract}
The research intended to establish the relationship between Zvishavane domestic water quality and selected disease patterns. Total levels of coliform, Escherichia Coli, chemical and other physical parameter levels in samples from selected water sources during the period March 2018 to January 2019 were evaluated. Zimbabwe National Water Authority (ZINWA) commercial laboratory methods were used to analyze thirty one randomly selected sources. This quantitative research results were compared with recommended limits from Standard Association of Zimbabwe (SAZS 560:1997) and World Health Organization (WHO).Five water sources had coliform counts ranging from $<1$ to 55 cfu per $100 \mathrm{ml}$ and Escherichia Coli from < 1 to $28 \mathrm{cfu}$ per $100 \mathrm{ml}$. Chloride levels of above $200 \mathrm{mg} / \mathrm{L}$ were obtained from eight borehole water sources. Levels of selected heavy metal ions were within the SAZS 560:1997 maximum allowable limits in all water samples. Sample levels for $\mathrm{Mg}^{2+}(29 \%)$ and total hardness $(32 \%)$ were above the maximum allowable levels. Tap water samples were within recommended limits for all measured parameters. Hypertension was first among the chronic disease conditions while diarrhoea and dysentery ranked second of the outpatient general diseases attended to at the Zvishavane District Hospital during 2018. 66 neonatal death were reported during the same time period. Zvishavane domestic water require research based pre-treatment methods before drinking. There is a possible link between the quality of water and the disease patterns. However these observations require further epidemiological studies to confirm the link.
\end{abstract}

\section{DOI: https://dx.doi.org/10.4314/jasem.v23i11.21}

Copyright: Copyright (C) 2019 Muleya et al. This is an open access article distributed under the Creative Commons Attribution License (CCL), which permits unrestricted use, distribution, and reproduction in any medium, provided the original work is properly cited.

Dates: Received: 07 October 2019; Revised: 11 November 2019; 24 November 2019

Keywords: Escherichia Coli, Hypertension, Diarrhoea

Zvishavane is a small town situated in the central part of the Midlands region of Zimbabwe. The mining town which is surrounded by largely small scale to medium gold miners is also situated in what was a very active Shabani Asbestos Mine. An estimated population of 45230 and a total of 12370 households are found in the small town according to the 2012 national census (Compendium of statistics 2014). There was no other census that was carried out in Zimbabwe since that time till the present time (2019). Situated in the agricultural natural region three Zvishavane is associated with warm to hot temperatures (average $27^{\circ} \mathrm{C}$ ) and infrequent rainfall patterns Chikodzi et al., (2013). The mean seasonal total infrequent rainfall for Zvishavane area is about $547 \mathrm{~mm}$ with a possible 745 $\mathrm{mm}$ and a minimum of $349 \mathrm{~mm}$ (Simba and Chayangira 2017). In Zimbabwe, urban councils and the Zimbabwe National Water Authority (ZINWA) are the major institutions responsible for service provision in urban areas (Zimbabwe report). Urban councils are responsible for the treatment and management of services from municipal water, sewerage and refuse removal departments while ZINWA is responsible for provision of raw water to the urban councils. The prevailing poor state of the Zimbabwe economy has made provision of general services to the population by local authorities in particular safe drinking water difficult (World Bank, 2017). The Zimbabwe electricity supply is currently erratic affecting the drinking water pumping capacity at the water treatment and distribution stage thereby reducing normal pump flow at household level. The Zimbabwe government has stated that it is committed to the Sustainable Development Goal (SDG) number six on clean water and sanitation where it is expected that by 2030, safe affordable drinking water should be accessible to all (VNR, 2017). A base line study to assess the water quality from March 2018 to January 2019 for Zvishavane was carried out in this study.

\section{MATERIALS AND METHODS}

Two liter volume samples were collected from 30 different sampling areas (Figure 1) that were randomly selected from tap, surface and underground, around Zvishavane town as per ZINWA sampling protocol The analysis was carried out using ZINWA 
commercial laboratory standard methods of quantification (Table1). Samples were collected in March, May, July, September, November in 2018 and January 2019. We collected data of prevalent disease from Zvishavane District Health Information office.

\section{RESULTS AND DISCUSSION}

Escherichia coli and Total Coliform: Figure 2 shows that five sampling points during the period of study which reported high E. coli levels ranging between 4-
$23 \mathrm{cfu}$ per $100 \mathrm{ml}$. However all sampling points (tap water or bore hole) reported $E$. coli counts of between $<1$ to $29 \mathrm{cfu}$ from the most contaminated sources during the period of sampling. The high levels of drinking water $E$. coli and total coliform count could explain why diarrhoea and dysentery are reported (Table 2) to be second on the top ten disease attended to during 2018 at Zvishavane district hospital with acute respiratory infections coming first of the reported cases.

\section{LOCATION OF ZVISHAVANE DISTRICT}

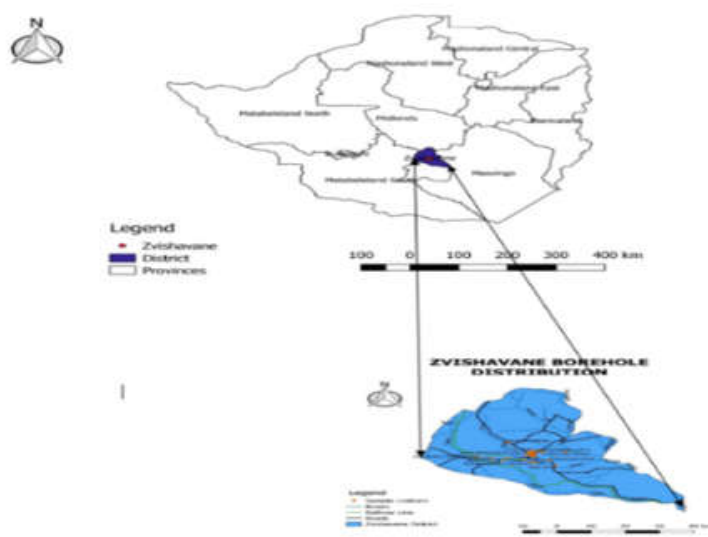

Fig 1: Map showing sampled borehole distribution in Zvishavane district, Zimbabwe

Table 1: Zimbabwe National Water Authority Laboratories methods of analysis used in this study

\begin{tabular}{|c|c|c|}
\hline Elements & Method code & Summary of method (s) \\
\hline $\mathrm{Mg}, \mathrm{Ca}, \mathrm{K}, \mathrm{Na}, \mathrm{Fe}, \mathrm{Cu}, \mathrm{Zn}, \mathrm{Mn}$ & CHW101 & Acid digestion and AAS finish \\
\hline Chloride & CHW102 & Titrimetric \\
\hline Sulphate & CHW103A & Turbidimetric \\
\hline Nitrate & CHW104 & Spectrophotometric \\
\hline $\mathrm{pH}$ & Test Not SADCAS Accredited & $\mathrm{pH}$ Electrode \\
\hline Total hardness & Test Not SADCAS Accredited & Calculation \\
\hline Conductivity, TDS & Test Not SADCAS Accredited & Electrode \\
\hline Total Alkalinity & CHW110 - Test Not SADCAS Accredited & Titrimetric \\
\hline Turbidity & CHW123- Test Not SADCAS Accredited & Turbidimetric \\
\hline T.V.C & M501 & $37^{\circ} \mathrm{C}, 48 \mathrm{hrs}$ PCA \\
\hline Coliforms & M502 Test Not SADCAS Accredited & $37^{\circ} \mathrm{C}, 24 \mathrm{hrs}$, Brill E.coli/Coli agar \\
\hline E. coli & M502 Test Not SADCAS Accredited & $37^{\circ} \mathrm{C}, 24 \mathrm{hrs}$, Brill E.coli/Coli agar \\
\hline
\end{tabular}

Results in Table 2 were obtained from the Zvishavane District hospital health information office indicating that diarrhoea and dysentery were second on a list of top ten conditions attended to in their outpatient department during 2018. Water with less than $1 \mathrm{cfu}$ E.coli count is considered to be low risk for drinking (WHO, 2017) and SAZS 560:1997 guidelines state that its equivalent to zero count.

However when considering that in many cases consumers harvest tap water when available in containers at home for use when the municipal water is not available, the level of risk increases. Zvishavane being situated in a very warm region of average temperatures above $27^{\circ} \mathrm{C}$, storage conditions could encourage the less than one colony to grow may be one of the causes of high incidence of diarrhoea shown by the hospital statistics in Table 2.

Turbidity, Total Dissolved Solids and Conductivity: During the period of study only three samples reported very high turbidity, 13.9 NTU from the Clinic well source at 6.9 NTU, Masvingo road borehole and 12.94 NTU from Ngomeyebani borehole. The rest of all samples were below 5 NTU (SAZS 560:1997). However, for total dissolved solids, SAZS 560:1997 
has no specified a limit but WHO recommended 1000 $\mathrm{mg} / \mathrm{L}$ and $26 \%$ of the water samples readings were above that limit. All tap water sources were below the $1000 \mathrm{mg} / \mathrm{L}$ indicating that most of the possible contaminants were left at the water treatment stage. Water containing TDS level below $1000 \mathrm{mg} /$ litre is usually acceptable to consumers (WHO, 2017). The palatability of drinking water has been rated by panels of tasters in previous studies in relation to its TDS level as follows: excellent, less than $300 \mathrm{mg} / \mathrm{litre}$; good, between 300 and $600 \mathrm{mg} /$ litre; fair, between 600 and $900 \mathrm{mg} /$ litre; poor, between 900 and $1200 \mathrm{mg} /$ litre; and unacceptable, greater than $1200 \mathrm{mg} /$ litre (WHO,
2017). Water with extremely low concentrations of TDS may lack flavour and usually corrosive to plumbing systems (WHO, 2017). Conductivity is a measure of water's capability to pass electrical flow which is directly related to the concentration of ions in the water. About $82 \%$ of all conductivity readings during the study were above the stipulated recommended limit of $700 \mu \mathrm{S} / \mathrm{cm}$ but below the maximum allowable limit of $3000 \mu \mathrm{S} / \mathrm{cm}$ by SAZS 560:1997. This can be expected because of the high magnesium, calcium sodium and anion levels that were recorded.

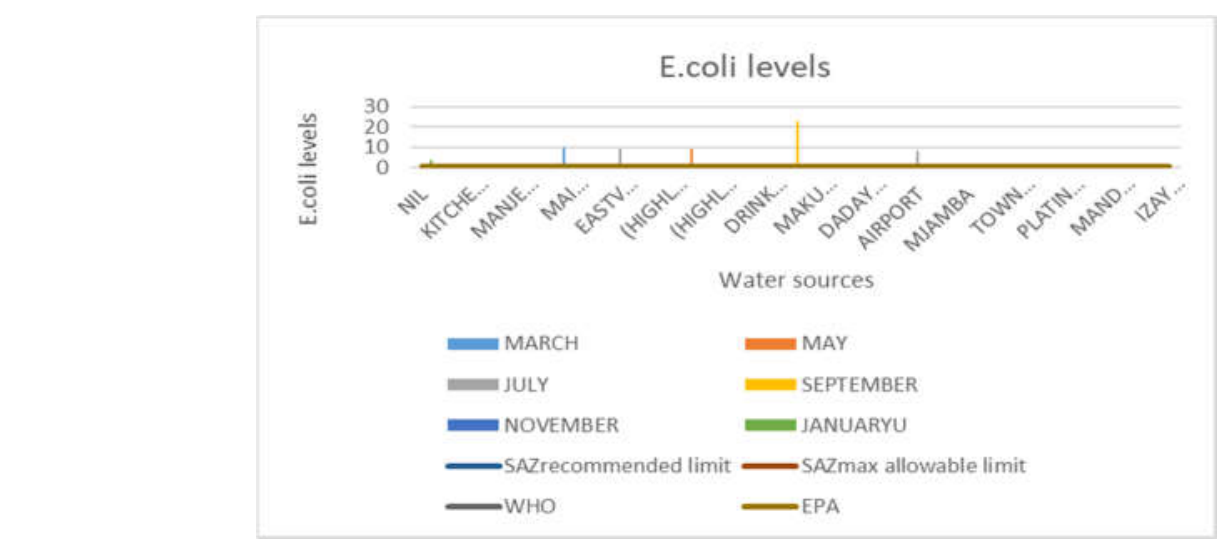

Fig 2: Escherichia coli counts from March 2018 to January 2019 from 19 boreholes, one water source and 11 tap water sources form Zvishavane urban and peri- urban area

Table 2 Top ten general disease conditions reported at Zvishavane district hospital in the period January 2018 to December 2018

\begin{tabular}{lll}
\hline Rank & DISEASE/ CONDITION & CASES \\
1 & Acute Respiratory Infections & 27117 \\
2 & Diarrhoea and dysentery & 8096 \\
3 & Skin Diseases & 8050 \\
4 & Injuries & 7476 \\
5 & Diseases of the eye & 4055 \\
6 & Ear Condition & 3929 \\
7 & Dental Conditions & 2325 \\
8 & Locally monitored diseases & 1356 \\
9 & Bilharzia & 521 \\
10 & Abortion & 348 \\
\hline
\end{tabular}

Hardness Level: Hardness in water is caused by presence dissolved metallic ions, usually of calcium and magnesium. $80 \%$ of the nineteen boreholes reported total hardness above the recommended limit of $500 \mathrm{mg} / \mathrm{L}$ (SAZS 560:1997). The borehole water reported high levels of magnesium and calcium $(\mathrm{Mg}=$ $211 \mathrm{mg} / \mathrm{L}$ and $\mathrm{Ca}=137.3 \mathrm{mg} / \mathrm{L}$; for Drink Water road); $(\mathrm{Mg}=186.6 \mathrm{mg} / \mathrm{L}$ and $\mathrm{Ca}=227.0 \mathrm{mg} / \mathrm{L}$; for Manjere MSU); $\mathrm{Mg}=151.1 \mathrm{mg} /$ Land $148.8 \mathrm{mg} / \mathrm{L}$; for Maglass Cottages); as well as chloride levels (Table 1). It has been reported before in previous research that water hardness can also be caused by presence several other dissolved metals such as aluminium, barium, strontium, iron, zinc, and manganese (WHO, 2011). This study established that both zinc (average $0.08 \mathrm{mg} / \mathrm{L}$ ) and iron (average of $0.156 \mathrm{mg} / \mathrm{L}$ ) levels were both below the SAZS 560:1997 limit of $0.1 \mathrm{mg} / \mathrm{L}$ and $0.3 \mathrm{mg} / \mathrm{L}$ respectively. Hardness is classified as soft, $0-17.1 \mathrm{mg} / \mathrm{L}$; slightly hard, $17.1-60 \mathrm{mg}$ / L; moderately hard, $60-120 \mathrm{mg}$ / L hard, $120-180 \mathrm{mg} /$ Land very hard, 180 \& over (USGS, 2014. Figure 6 depicts the total alkalinity values obtained thought this study. The (SAZS 560:1997) guidelines does not have any limits but the study show that tap water levels were all below 200 $\mathrm{mg} / \mathrm{L}$ but all boreholes were all above the $200 \mathrm{mg} / \mathrm{L}$. The values further indicate high levels of ions such as $\mathrm{Mg}^{2+} \mathrm{Ca}^{2+}$ and corresponding anions that were identified in Table 3. There is evidence from epidemiological studies for a protective effect of 
magnesium or hardness on cardiovascular mortality Stevanovic et al., \{2017). Therefore despite the other risks such as E. coli contamination and elevated sodium levels in borehole water, the water may be of benefit as source of magnesium and calcium which can protect from cardio vascular disease and are also necessary in bone and teeth development in humans.

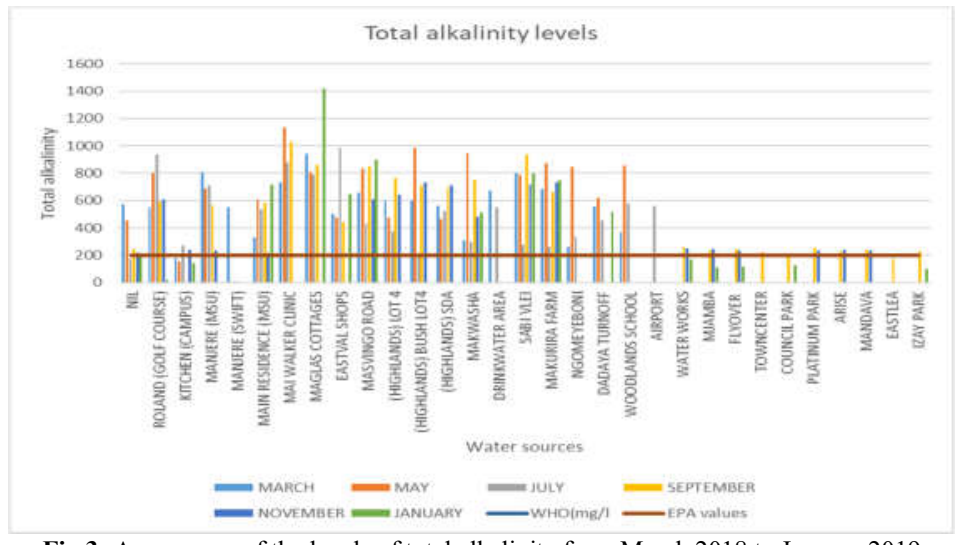

Fig 3: A summary of the levels of total alkalinity from March 2018 to January 2019

The Heavy Metal levels: Only one sampling point (Roland Golf Club, $1.07 \mathrm{mg} / \mathrm{L}$, July 2018) out of the combined tap water, open well and borehole sources reported above SAZS 560:1997 recommended limits of $0.1 \mathrm{mg} / \mathrm{L}$ copper, but below the maximum allowable limit of $2 \mathrm{mg} / \mathrm{L}$. Concentrations in drinking-water range is likely to be a result of the corrosion of interior copper plumbing. Zvishavane samples sources indicated acceptable levels of copper ion in both tap, well and borehole water. The ten tap water sources reported an average of $0.156 \mathrm{mg} / \mathrm{L}$ of iron during the period of sampling with two of the points reporting levels of $0.54 \mathrm{mg} / \mathrm{L}$ (Platinum Park) and $0.80 \mathrm{mg} / \mathrm{L}$ (Arise) ranging was between 0.01-0.54 mg/L. This may be attributed to the high alkalinity value ( 255 and240 $\mathrm{mg} / \mathrm{L}$ respectively), steel fixtures on water pipes could be corroding into drinking water. SAZS 560:1997guideline set the recommended iron limits at $0.3 \mathrm{mg} / \mathrm{L}$ and maximum allowable limit at $1 \mathrm{mg} / \mathrm{L}$ ). The high levels of iron in samples could explain the observed typical light brown color and taste of Zvishavane drinking tap water. It has been reported that at levels above $0.3 \mathrm{mg} / 1$, iron stains laundry and plumbing fixtures (WHO, 2017). The 19 borehole water samples reported a similar average of 0.156 $\mathrm{mg} / \mathrm{L}$ with a range of values between $0.1-1.14 \mathrm{mg} / \mathrm{L}$ (Masvingo road). Levels of $0.62 \mathrm{mg} / \mathrm{L}$ in Nil suburb 18 and $0.61 \mathrm{mg} / \mathrm{L}$ at the East Vaal shops in May 2018 were also reported. Combined tap water and borehole water samples reported manganese levels within SAZS 560:1997 recommended limits although (17\%) reported manganese levels higher than the recommended limits of $0.1 \mathrm{mg} / \mathrm{L}$ indicating that water treatment may not have in effect into the removal of the heavy metal ion from tap water. Although manganese is an essential element for humans although previous epidemiological studies have suggested that soluble manganese is associated with adverse effects on learning in children (WHO, 2017).

Tap water samples reported low magnesium levels of $27.29 \mathrm{mg} / \mathrm{L}$ which is below the SAZS 560:1997 limit of $70 \mathrm{mg} / \mathrm{L}$. Bore hole samples reported much higher concentrations such as $211.4 \mathrm{mg} / \mathrm{L}$ (Drink Water), $198.8 \mathrm{mg} / \mathrm{L}$ Sabi Vlei; 151.1 Maglass Cottage. Calcium levels vary from $227 \mathrm{mg} / \mathrm{L}$ (Manjere MSU borehole) to $7 \mathrm{mg} / \mathrm{L}$ Council Park tap water. There no limit for calcium in drinking water from SAZS 560:1997. Previous research has indicated that analysis concluded that hard water could be used to prevent ischemic heart disease (IHD) or coronary heart disease, through drinking Stevanovic S., et al., (2017) although high levels of magnesium could affect the water taste particularly in the presence of sulphate and chloride which is the case for Nil, Swift, Manjere MSU residence and East Vaal shops boreholes (Table 2).

In general, Zvishavane tap water sampled sources reported low sodium ion levels and are within recommended limits by SAZS: 560:1997 but the situation was different for boreholes because $52.38 \%$ of them reported sodium ion concentration of above $120 \mathrm{mg} / \mathrm{L}$ in sampled water. High sodium levels of $258.80 \mathrm{mg} / \mathrm{L}$ from Manjere Midlands State University (MSU) borehole in July 2018; $287.70 \mathrm{mg} / \mathrm{L}$ from open well source situated a private clinic and $995.00 \mathrm{mg} / \mathrm{L}$ from East Vaal borehole situated at a popular eatery. Zvishavane district hospital statics for chronic diseases (Table 3) indicate there is a link between the quality of water and reported disease conditions 
Table 3: Top ten outpatient chronic diseases condition (Non- HIV related) reported at Zvishavane district hospital, Zimbabwe

\begin{tabular}{rlc}
\hline Rank & DISEASE/ CONDITION & Registered Patients regularly attending \\
1 & Hypertension & 10560 \\
2 & Diabetes & 2318 \\
3 & Asthma & 1528 \\
4 & Epilepsy & 928 \\
5 & Mental Sickness & 770 \\
6 & Chronic Heart Failure & 222 \\
7 & Rheumatoid heart disease & 168 \\
8 & Conditions requiring Rehab & 79 \\
9 & Other Cancers & 5 \\
10 & Leprosy & 12 \\
\hline
\end{tabular}

Table 4: Average anion levels from boreholes and well sources from March 2018 to January 2019

\begin{tabular}{|c|c|c|c|c|c|c|}
\hline & \multicolumn{2}{|c|}{ COORDINATES } & \multirow[b]{2}{*}{ Source Identity } & \multicolumn{3}{|c|}{ Average Anion Concentration in $\mathrm{mg} / \mathrm{L}$} \\
\hline & $\mathrm{X}$ & $\mathrm{Y}$ & & $\mathrm{SO}_{4}^{2-}$ & $\mathrm{NO}_{3}$ & $\mathrm{Cl}^{-}$ \\
\hline 1 & -20.354537 & 30.0674 & NIL & 21.7 & 82.2 & 119.9 \\
\hline 2 & -20.351180 & 30.055283 & ROLLAND SPORTS CLUB & 45.5 & 26.6 & 118.5 \\
\hline 3 & -20.339177 & 30.034765 & MANJERE (MSU) & 29.4 & 99.8 & 311.5 \\
\hline 4 & -20.317609 & 30.059197 & CLINIC Well source & 32.4 & 45.4 & 200.2 \\
\hline 5 & -20.339379 & 30.035268 & SWIFT & 161.9 & 70.2 & 169.5 \\
\hline 6 & -20.314268 & 30.063296 & MAGLASS COTTAGES & 31.5 & 33.3 & 341.7 \\
\hline 7 & -20.310747 & 30.064713 & EASTVAAL SHOPS & 31.2 & 27.9 & 301.7 \\
\hline 8 & -20.286294 & 30.077036 & MASVINGO ROAD & 17.4 & 24.9 & 20.1 \\
\hline 9 & -20.291615 & 30.05817 & CHURCH & 31.4 & 24.7 & 117.2 \\
\hline 10 & -20.318453 & 30.060484 & DRINKWATER ROAD & 41.3 & 31.3 & 194.5 \\
\hline 11 & -20.371388 & 30.119327 & SABI VLEI & 103.7 & 35.9 & 76.1 \\
\hline 12 & -20.343557 & 30.101563 & FARM & 15.7 & 41.5 & 78.8 \\
\hline 13 & -20.242808 & 29.994494 & NGOMEYEBANI & 94.3 & 26.1 & 73.0 \\
\hline 14 & -20.340584 & 29.979097 & DADAYA TURN OFF & 2.7 & 14.4 & 71.5 \\
\hline 15 & -20.292273 & 30.146003 & SCHOOL & 11.5 & 11.4 & 125.0 \\
\hline 16 & -20.318809 & 29.914190 & AIRPORT & 34.4 & 14.0 & 98.0 \\
\hline 17 & -20.299067 & 30.055362 & MAKWASHA & 79.2 & 44.2 & 510.8 \\
\hline 18 & -20.294323 & 30.065882 & HIGHLANDS LOT 4 & 24.9 & 19.0 & 306.2 \\
\hline \multirow[t]{2}{*}{19} & -20.289527 & 30.062305 & HIGHLANDS LOT 4 BUSH & 20.1 & 14.7 & 336.2 \\
\hline & & & $\begin{array}{l}\text { SAZS 560:1997 recommended limit } \\
\text { SAZS 560:1997 Allowable limit }\end{array}$ & $\begin{array}{c}10 \\
50\end{array}$ & $\begin{array}{c}200 \\
500\end{array}$ & $\begin{array}{c}200 \\
500\end{array}$ \\
\hline
\end{tabular}

Supply of safer tap water by Zvishavane town council municipality is erratic forcing consumers to rely on borehole water sources. If the Zimbabwe National Census Statistics of 2012 (much higher now, population growth rate was estimated to be $1 \%$ ) of 45 230 people in Zvishavane town are considered, then the condition of hypertension is claiming $23.3 \%$ of the population.

Maximum permissible limits for nitrate in drinking water is $50 \mathrm{mg} / \mathrm{l}$ (WHO, 2003; SAZS 560:1997). Although there was a huge variation in nitrate concentration from one sampling episode to another, the averages indicated in Table 4 still generally depict the relative differences from one source to another. The Zvishavane tap water sources all reported nitrate levels within recommended limits by SAZS: 560:1997 (average of $2.32 \mathrm{mg} / \mathrm{L}$ September 2018; $2.24 \mathrm{mg} / \mathrm{L}$ November 2018 and $0.04 \mathrm{mg} / \mathrm{L}$ January 2019). However, high nitrate values were reported at $26.31 \%$ of the borehole water samples (Nil; Manjere swift borehole, Makwasha, Sabi Vlei, and Ngomeyebani) during the sampling period (Table 4). Nil borehole supports $100+$ households composed of laid off workers of the previously Shabani asbestos mine making a poor community. The rest of the boreholes had nitrate levels below $50 \mathrm{mg} / \mathrm{L}$.

Makwasha borehole is used by two communities of Makwasha and Mandava high density suburbs supplying approximately 50 households with drinking water. Reports from verbal interviews at Swift borehole state that the borehole was sunk on an area which used to a cattle pan, thereby explaining the possible source of nitrate as Considering that there were 66 neonatal deaths in 2018 at the hospital (Zimbabwe Health Information System, 2018), there is need for an epidemiological study to establish if there is a link between any deaths that the hospital experienced and water quality that was used for drinking by the pregnant mothers. Reports from previous research indicated that maternal drinking water nitrate intake during pregnancy could cause a range of pregnancy outcomes, including spontaneous abortion, foetal deaths, prematurity, intrauterine growth retardation, low birth weight, congenital malformations, and neonatal deaths Ward et al., (2018). Levels above $50 \mathrm{mg} / \mathrm{L}$ of $\mathrm{NO}_{3}^{-}$in water 
exposed infants to have been reported before to cause methaemoglobinaemia (leading to blue baby syndrome), thyroid effects and gastric cancer in adults Ward et al., (2018). Only one borehole reported above the recommended limit $258.8 \mathrm{mg} / \mathrm{L}$ during the month of July at Manjere MSU borehole (Table 4). Most water sources had chloride levels were within the SAZS 560:1997 recommended limits of $200 \mathrm{mg} / \mathrm{L}$ with $24.6 \%$ of samples above this limit and $0.04 \%$ reporting above the maximum allowable limits of 500 $\mathrm{mg} / \mathrm{L}$.

Conclusion: There is a possible link between the quality of water and the reported disease patterns. The findings of the study recommend that due to the high incidence of hypertension reported by the district hospital, observations require epidemiological studies to investigate if high sodium ion levels in some borehole water samples are linked to any hypertension cases. Zvishavane drinking water needs further treatment before drinking especially the open well source.

Acknowledgements: The Authors wish to acknowledge the kind support of Midlands State University, Zimbabwe Research Board Funding and the Zimbabwe National Water Authority (ZINWA) commercial laboratory for the analysis.

\section{REFERENCES}

Chikodzi, D; Zinhiva, H; Simba, FM; Murwendo, T (2013). Reclassification of agro-ecological zones in Zimbabwe - the rationale, methods and expected benefits: the case of Masvingo Province. J. of Sust. Dev. in Afr. 15 (1).

Compendium of statistics (2014). Zimbabwe national statistics agency. Zimstat pp 39. Causeway, Harare. URL: http://www.zimstat. co.zw/ sites/default/files/img/publications/Other/Compendi um 2014 0.pd

Holloway, JM; Dahlgren, RA (2002). Nitrogen in rock: Occurrences and Biogeochemical Implications $G l$. Biogeochem. Cycles 16 (4) 1118.

SAZ-560 (1997). Standards Association of Zimbabwe. National Standards Body for Zimbabwe.

Simba, FM; Chayangira J (2017). Rainfall Seasons Analysis as a Guiding Tool to Small Holder Farmers in the Face of Climate Change in Midlands in Zimbabwe J. of Earth Sci. \& Cl. Ch. 8 (3).

Stevanovic, S; Nikolic, M; Ilic. MD (2017). Calcium and Magnesium in Drinking Water as Risk factors for
Ischemic Heart Disease Pol. J. Environ. Stud. Vol. 26, No. 4 (2017), 1673-1680.

USGS Office of water quality (2016). U.S. Department of the Interior U.S. Geological Survey. URL: https://www.usgs.gov/special-topic/water-scienceschool/science/hardness-water.

Ward, MH; Jones, RR; Brender, JD; De Kok, TM; Weyer, PJ; Nolan, BT; Villanueva, CM; Van Breda, SG (2018). Drinking Water Nitrate and Human Health: An Updated Review Intl J. of Envi. Res. and Pub. He.15 1557.

WHO (2004). Sulfate in Drinking-water Background document for development of WHO Guidelines for Drinking-water Quality.URL: https://www.unicef.org/publications/files/ENAcute _Diarrhoea_reprint.pdf.

WHO Background document for development of Guidelines for Drinking-water Quality Nitrate and nitrite in drinking-water. URL: https://www.who.int/water_sanitation_health/dwq/c hemicals/nitratenitrite.pdf

World Bank (2017). Zimbabwe Economic Update. The state in the economy. URL http://pubdocs.worldbank.org/en/908481507403754 670/Annual-Report-2017-WBG.pdf.

World Health Organization (2011) Hardness in Drinkingwater document for development of WHO Guidelines for Drinking-water Quality URL: https://www.who.int/water_sanitation_health/dwq/c hemicals/hardness.pdf..

World Health Organization 2017. Guidelines for drinking water quality: Fourth edition incorporating the first addendum.URL: $\quad$ https://www.who.int/newsroom/fact-sheets/detail/human-rights-and-health.

Zimbabwe Health Information System (2018). Zimbabwe. Ministry of Health and Child Welfare. Zimbabwe Government.

Zimbabwe Report. (2010). Water Resource Management, Supply and Sanitation. Chapter 7 URL: https://www.afdb.org/fileadmin/uploads/afdb/Docu ments/Generic-Documents/9.\%20Zimbabwe \%20Report_Chapter\%207.pdf

Zimbabwe Voluntary National Review (VNR) of SDGs for the High Level Political Forum (2017). URL: https://sustainabledevelopment.un.org/content/docu ments/15866Zimbabwe.pdf. 